\title{
OUTBREAK OF INFLUENZA TYPE A (H1N1) IN IPORANGA, SÃO PAULO STATE, BRAZIL
}

Terezinha Maria de PAIVA(1), Maria Akiko ISHIDA(1), Kazue Aparecida Yamamoto HANASHIRO(2), Regina Maria SCOLARO(2), Maria Gisele GONÇALVES(1), Margareth Aparecida BENEGA(1), Meire Aparecida S. OLIVEIRA(1), Aurea Silveira CRUZ(1) \& Sueko TAKIMOTO(1)

\begin{abstract}
SUMMARY
From June to July 1999 an outbreak of acute respiratory illness occurred in the town of Iporanga. Out of a total of 4,837 inhabitants, 324 cases were notified to the Regional Surveillance Service. Influenza virus was isolated from $57.1 \%$ of the collected samples and $100 \%$ seroconversion to influenza A (H1N1) was obtained in 20 paired sera tested. The isolates were related to the A/ Bayern/07/95 strain (H1N1). The percentages of cases notified during the outbreak were $28.4 \%, 29.0 \%, 20.7 \%, 6.2 \%$ and $15.7 \%$ in the age groups of $0-4,5-9,10-14,15-19$ and older than 20 years, respectively. The highest proportion of positives was observed among children younger than 14 years and no cases were notified in people older than 65 years, none of whom had been recently vaccinated against influenza. These findings suggest a significant vaccine protection against A/Bayern/7/95, the H1 component included in the 1997-98 influenza vaccine for elderly people. This viral strain is antigenically and genetically related to A/Beijing/ 262/95, the H1 component of the 1999 vaccine. Vaccines containing A/Beijing/262/95 (H1N1) stimulated post-immunization hemagglutination inhibition antibodies equivalent in frequency and titre to both A/Beijing/262/95-like and A/Bayern/7/95-like viruses. Thus, this investigation demonstrates the effectiveness of vaccination against influenza virus in the elderly.
\end{abstract}

KEYWORDS: Influenza virus; Influenza surveillance; Influenza vaccine

\section{INTRODUCTION}

Influenza is a highly contagious, acute respiratory disease and is responsible each year for local, regional, or worldwide epidemics ${ }^{26}$. Because of this continuing threat to Public Health, surveillance is the only tool suitable to detect new strains and to adopt strategies to avoid dramatic consequences of the dissemination of new strains ${ }^{32}$. No other acute febrile disease with respiratory symptoms can spread so rapidly to a large number of people.

Influenza virus incidence is relatively high among children and young adults, but serious morbidity and mortality are highest among people older than 65 years and people of any age who have medical conditions that place them at risk for complications from influenza ${ }^{7}$.

This report describes results from a collaborative study between the "Divisão de Vigilância Epidemiologica da DIR XVII Registro (Direção Regional da Saúde)" and the Respiratory Virus Laboratory, Instituto Adolfo Lutz to evaluate an outbreak of acute respiratory illness in the town of Iporanga.

\section{MATERIALS AND METHODS}

Population - The population studied lives in the urban area of Iporanga located in the Southeast region of Brazil. The territorial area and population density are $1162 \mathrm{Km}^{2}$ and 4 inhabitants $/ \mathrm{Km}^{2}$, respectively. Nearly $45.7 \%$ of the total population of 4,837 lives in the town. The most important sectors of Iporanga's economy are agriculture and tourism. The climate of this region has been defined as subtropical according to the Köppen classification ${ }^{11}$. Regarding health services, Iporanga has primary health care, and a local hospital. In addition, family physicians and six health care services are located in the urban and rural area, respectively.

Collection of throat specimens and blood samples - A total of seven throat swabs were collected during the peak of the outbreak from patients 0 to 14 years of age with acute respiratory illness. The patients presented fever, headache, myalgia, pharyngitis, and some of them reported abdominal pain, nausea and vomiting after the initial symptoms. Paired serum samples were collected from patients 0 to 12 years of age with influenza-like illness. An acute phase specimen was collected within five to seven days after the onset of the illness, and a convalescent phase specimen was collected 2-3 weeks later.

Processing throat swabs for virus isolation - Swabs were removed from the collection vial and vigorously shaked in $2.5 \mathrm{~mL}$ of cell culture medium in a vortex mixer and $1000 \mathrm{U} / \mathrm{mL}$ of penicillin and $1000 \mu \mathrm{g} / \mathrm{mL}$ of streptomycin were added. Cell cultures of MDCK (Mardin Darby canine), HEp-2 (human epidermoid carcinoma of the larynx), Vero (African green monkey, kidney) were inoculated. The Hep-2 cell culture

(1) Instituto Adolfo Lutz, Serviço de Virologia, Lab. de Vírus Respiratórios, Av. Dr. Arnaldo 355, 01246-902 São Paulo, SP, Brasil. Phone (55 11) 3068 2913

(2) Divisão de Vigilância Epidemiológica da DIR XVII Registro, SP, Brasil.

Correspondence to: Terezinha Maria de Paiva, Instituto Adolfo Lutz, Lab. de Vírus Respiratórios, Av. Dr. Arnaldo 355, 01246-902 São Paulo, SP, Brasil. e-mail: tterezinha@ uol.com.br 


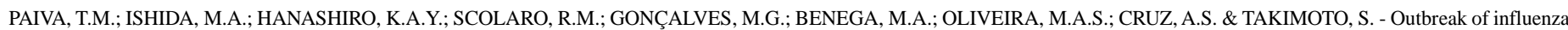
type A (H1N1) in Iporanga, São Paulo State, Brazil. Rev. Inst. Med. trop. S. Paulo, 43(6):311-315, 2001.

was maintained in Eagle's minimal essential medium with $2 \%$ fetal calf serum, while Vero and MDCK cell cultures were maintained in Eagle's minimal essential medium without serum and supplemented with $2 \mu \mathrm{g} /$ $\mathrm{mL}$ trypsin. The cultures were replenished with fresh medium every 3 days and examined every other day for cytopathic effect or for the presence of hemadsorption over a period of 14 days. The hemadsorption test was done seven days after inoculation of clinical specimens in culture tubes of Vero cells with guinea pig erythrocytes and of MDCK with chicken erythrocytes. Virus isolated from cell culture was identified by immunofluorescence with monoclonal antibodies of the respiratory Panel 1 Viral Screening \& Identification Kit, (Chemicon International Inc., Temecula, CA). Isolated viruses were sent to the Influenza Branch at the Centers for Disease Control and Prevention - Atlanta, GA, for further antigenic and genetic analysis.

Immunofluorescence assay (IF) - Cells from positive cultures were prepared for IF as described previously ${ }^{29}$. Monoclonal antibodies from the Respiratory Panel 1 Viral Screening \& Identification Kit (Influenza A and B, Respiratory Syncytial Virus, Adenovirus and Parainfluenza Viruses types 1, 2 and 3) from Chemicon International, Inc. (Temecula, $\mathrm{CA}$ ), were used as reagents for IF. Cells were harvested, washed with sterile phosphate buffered saline PBS ( $\mathrm{pH}$ 7.2) and resuspended in a few drops of PBS. Two cell smears on each microscope slide were prepared and then fixed in anhydrous acetone for 10 minutes at $4{ }^{\circ} \mathrm{C}$. Uninfected cells were used as control. Cells were incubated with $25 \mu \mathrm{L}$ of the monoclonal antibodies for 30 minutes at $37^{\circ} \mathrm{C}$. After washing with PBS, $25 \mu \mathrm{L}$ of fluorescein-conjugated antimouse $\mathrm{IgG}$ were added and incubated for another $30 \mathrm{~min}$. After three washes with PBS, the specimens were examined under a fluorescent microscope. All clinical specimens were read by two observers. Doubtful or discrepant samples were restained and read at least twice to check for reproducibility.

Hemagglutination inhibition test - Sera were inactivated by heating at $56^{\circ} \mathrm{C}$ for 30 minutes and the nonspecific inhibitors of hemagglutination were destroyed with receptor-destroying enzyme (RDE) just prior to titration. Paired serum samples were tested by hemagglutination / inhibition for antibodies against influenza virus A subtypes and influenza virus type $\mathrm{B}$. The strains for the studies included influenza viruses $\mathrm{A} /$ Taiwan/1/86-like H1N1, A/Beijing/262/95-like H1N1, A/Wuhan/359/ 95-like H3N2, A/Sydney/05/97-like H3N2, B/Guangdong/8/93, B/ Beijing/184/93 and B/Beijing/234/97 reference antigens provided by the World Health Organization (WHO) kit and A/Bayern/07/95-like $\mathrm{H} 1 \mathrm{~N} 1$ strains isolated during the outbreak. Hemagglutination/inhibition for antibodies against parainfluenza virus was also performed. Titration of hemagglutination/inhibition antibodies was performed on U- shaped 96-well microplates by a standard method with 4 units of virus and $0.5 \%$ red blood cells ${ }^{20}$.

An indirect immunofluorescence test was done for adenovirus and respiratory syncytial virus for the detection of antibody response as described elsewere ${ }^{31}$.

In adddition, Elisa was performed for measles, rubella and dengue viruses for the detection of antibody response as follows:

Measles virus - Measles virus specific IgM was tested with three different kits: 1) Measles IgM capture Enzyme Immunoassay provided by the Centers for Disease Control and Prevention (CDC), Atlanta,
Georgia; 2) Measles IgM capture Enzyme Immunoassay (Chemicon International Inc, Temecula, CA); 3) Enzygnost ${ }^{\mathrm{R}}$ anti-measles virus/IgM (Dada Behringer Gmbh, Germany), as part of the Adolfo Lutz Institute normal routine for measles diagnosis.

Rubella virus - The assay used for the detection of Rubella virus antibodies was the Rubenostika IgM II microelisa system (Organon Teknika, Boxtel, NL).

Dengue virus - Mac-Elisa was carried out as described elsewere ${ }^{13}$. Conjugated indicator antibodies and ABTS substrate (2,2-azino-di-(3 ethil benzothiazoline sulfonic acid) were obtained from Jackson Immuno Research Laboratories and Kirkegaard \& Perry Laboratories (KPL), respectively. Anti-Human IgM was provided by Sigma; serotypes of dengue virus type 1 and dengue virus type 2 were produced in Swiss suckling mouse brain by the personnel of the Arthropod-borne Disease Laboratory of Adolfo Lutz Institute.

\section{RESULTS}

During the 20 days of the oubreak, 324 people became ill, and a higher concentration of notified cases between 06/25/99 and 07/04/99 was clearly demonstrated in (Fig. 1). Work absenteism was remarkable and the local school was closed. Cases also occurred among health service attendants, nurses and physicians. Only seven throat swabs were collected because when the outbreak was detected, appropriate media for the collection of samples were not routinely availabe at health care facilities in Iporanga County. By the time proper collection kits were made available, only seven samples were collected. Of seven throat swabs submitted for virus isolation, four $(57.1 \%)$ were positive for influenza virus antigenically related to A/Bayern/07/95 (H1N1). Serological tests demonstrated seroconversion to the influenza virus strains A/Taiwan/1/ 86-like H1N1 and the homologous strains A/Bayern/07/95-like H1N1 in $100 \%$ of the samples studied. On the other hand, seroconversion against influenza virus A/Beijing/2692-like H1N1 strains was obtained in only one case. Among the 20 paired samples of sera studied, two mixed infection $(10 \%)$ with parainfluenza virus were detected. In addition, mixed infection with both influenza virus subtypes H1N1 and A/Wuhan/ 359/95-like H3N2 was diagnosed in four patients (20\%) and with A/ Sydney/05/97-like H3N2 in three patients (15\%). No seroconversion to influenza B viruses, adenovirus or respiratory syncytial virus was obtained. In addition, serological tests were negative for measles, dengue and rubella.

The percentages of notified cases during the outbreak by age group were $28.4 \%, 29.0 \%, 20.7 \%, 6.2 \%$ and $15.7 \%$ for $0-4,5-9,10-14,15-19$ and older than 20 year subjects, respectively (Table 1). The highest percentage was observed among children younger than 14 years.

\section{DISCUSSSION}

In the present study a higher proportion of notified cases was observed among teenagers living in the urban area of the county where there is only one public school. According to public health authorities, the outbreak was restricted to the urban area. The only case in the 50-60 year old age group was a 52 year old woman who had not been vaccinated, and no cases among people older than 65 years were notified. Laboratory confirmation of influenza infection during the acute respiratory illness 


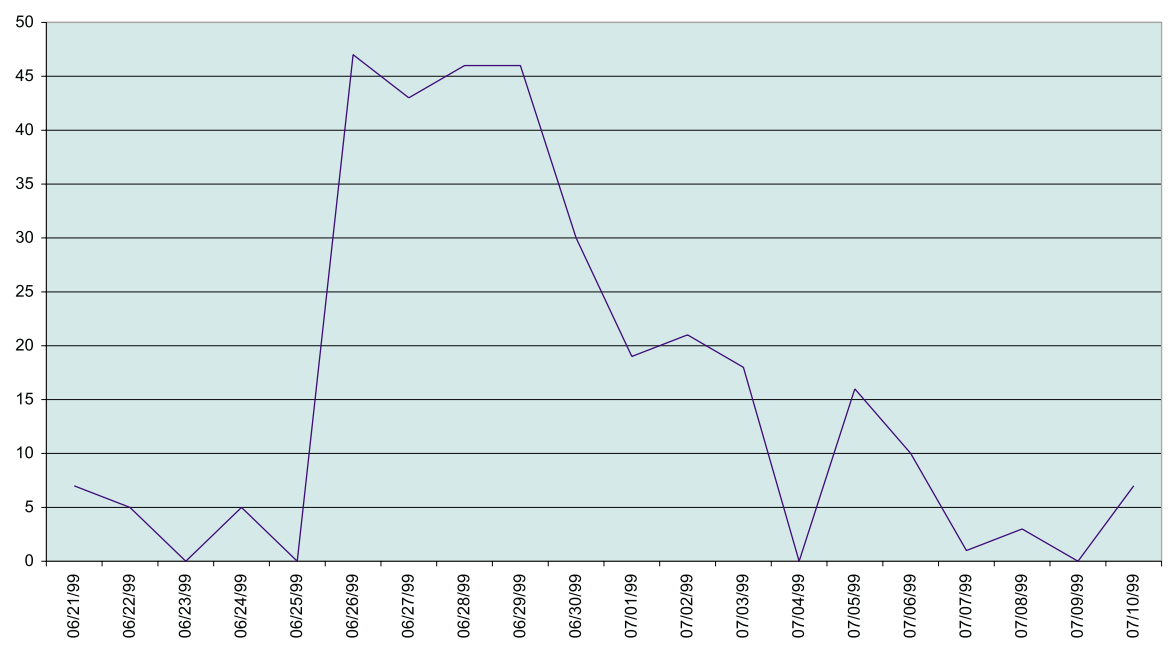

Fig.1 - Distribution of acute respiratory illness cases in Iporanga, by day, during June-July 1999.

Table 1

Age distribution of acute respiratory illness cases in Iporanga*

\begin{tabular}{cccc}
\hline $\begin{array}{c}\text { Age group } \\
\text { (years) }\end{array}$ & Population & $\%$ & $\begin{array}{c}\text { Number } \\
\text { of cases }\end{array}$ \\
\hline $0-4$ & 569 & 28.4 & 92 \\
$5-9$ & 593 & 29.0 & 94 \\
$10-14$ & 587 & 20.7 & 67 \\
$15-19$ & 545 & 6.2 & 20 \\
$20-49$ & 2488 & 15.7 & 51 \\
\hline Total & 4782 & 100.0 & 324 \\
\hline
\end{tabular}

* Data obtained from June to July, 1999.

Provided by the DIR XVII Registro - D.V.E.

in Iporanga was obtained by both virus isolation and serologic tests. This investigation demonstrated high seroconversion titers for influenza virus of subtype $\mathrm{H} 1$. The high seroconversion titers to the homologous influenza virus strains A/Bayern/07/95-like H1N1 and the lack of antibody response to the influenza virus strain A/Beijing/262/95-like H1N1 agree with DAVENPORT et al. ${ }^{4}$ who demonstrated that the sera of children contain antibodies of limited scope essentially oriented toward the dominant antigens of the strains recently prevailing. The results from that study supported the theory that during the initial infections with influenza viruses, which occur predominantly in childhood, the major antigens of the prevailing strains have a unique effect upon the antibody forming mechanisms which persists throughout life and largely determines the character of the future antibody with which this cohort of the population will respond when subsequently exposed to related virus strains.

The high seroconversion titers against the influenza virus strains A/ Taiwan/01/86-like H1N1 was probably due to the circulation of these strains in the Southeastern region of Brazil during 1996. The higher incidence of subtype (H1N1) during the influenza season, of 1996, when compared to previous years, was observed worldwide ${ }^{18}$.
The only seroconversion titer for the three different H1N1 strains was obtained from a serum sample collected from a 10 year old child, and the titers were 40-320, $<10-320$ and $<10-40$ for the A/Taiwan/01/ 86, A/Bayern/07/95 and A/Beijing/262/95 influenza virus strains, respectively. It was also observed that the high seroconversion titers to A/Taiwan/01/86-like H1N1 did not protect the children against influenza virus strain A/Bayern/07/95, due to the fact that this strain was antigenically distinguishable from the reference strains A/Taiwan/1/86 and A/Texas/36/91 (H1N1) which were circulating worldwide and an H1 vaccine component was included in the 1997-98 season ${ }^{33}$.

In addition, the mixed infection obtained between influenza virus $\mathrm{H} 1$ and $\mathrm{H} 3$ subtypes was also demonstrated. Since these subtypes have been cocirculating worldwide since 1977 as reported by KUNG et al. ${ }^{12}$, the results of this study also suggest that during an epidemic natural infections with both subtypes may occur. The incidence of mixed infection by both influenza A subtypes has already been described ${ }^{5,10,36,37}$. FRANK et al. ${ }^{6}$, in 1983, demonstrated that individuals may be infected with two subtypes of influenza A virus during the same season, and found that this incidence was $12 \%$ in school children during the 19801981 influenza season, in the Houston Family Study, during a period of two mixed outbreak due to two subtypes of influenza A virus (H3N2 and H1N1). On the other hand, the antibody titer to A/Wuhan/359/95like H3N2 (95\%) and A/Sydney/05/97-like H3N2 (80\%) detected in paired sera may be due to cross-reaction with previous related strains. According to SMITH \& DAVIES ${ }^{24}$, the HI antibody produced in response to infection with one strain of the H3N2 series often cross-reacted with subsequent variants. Regarding influenza B viruses, low antibody levels against influenza B/Beijing/184/93 were detected in $15 \%$ of the studied samples.

Influenza virus incidence is generally high among children and young adults, but serious complications are much more likely to occur among the very young ( $<1$ year of age) and the elderly (those over 65$)^{14,25,27}$. Studies from the 1950s and early 1960s have suggested that school age children are the most important source of the spread of virus within communities $^{3,23}$. Similarly, as demonstrated in previous studies ${ }^{3,23,28}$, 


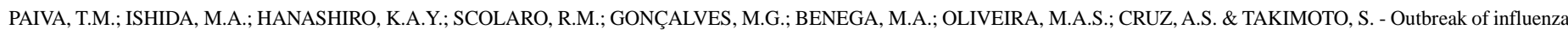
type A (H1N1) in Iporanga, São Paulo State, Brazil. Rev. Inst. Med. trop. S. Paulo, 43(6):311-315, 2001.

school age children introduce the infection into their families. In addition, pre-school age children also have an important role in producing community spread of influenza virus, presumably through casual and organized play activities ${ }^{8,15}$. Despite a high frequency of influenza in children and young adults, few people in these age groups have complications or require hospitalization (approximately 6 per 10,000 individuals in the age group of 5 to 24 years $)^{22}$. The higher hospitalization rate occurs in the very young (under one year old) and in the elderly ${ }^{2,9}$ with rates estimated at 50 and 30 to 38 per 10,000 , respectively ${ }^{22}$. Pneumonia is the major cause of hospitalization in the elderly. Independent of the age of the patient, chronic conditions such as cardiovascular disease, pulmonary disease, diabetes mellitus and asthma can considerably increase the probability of severe or complicated influenza, requiring hospitalization, and increase the death rate by approximately 40-fold. Combined pulmonary and cardiovascular disease can increase the risk of death by 800 -fold ${ }^{1}$.

Influenza A/Bayern/07/95 circulated in the United States between October 1995 and February 1996 and 50\% of the viruses isolated in South America between April and October 1996 were closely related to $\mathrm{A} /$ Bayern/07/95. Influenza virus related to A/Bayern/07/95 was first isolated in Brazil in June 1996 in the city of Curitiba and in July 1996 in the city of São Paulo, in the South and Southeast regions of Brazil, respectively. This virus was the only subtype H1N1 influenza virus detected in 1997 in the Southeastern region of Brazil. During the influenza season of 1998, it was detected only in São José do Rio Preto. So far, this strain has been detected only in the Southern and Southeastern regions of Brazil $^{18}$.

In early April 1999 about 9 million doses of influenza vaccine were administered to elderly people in Brazil ${ }^{30}$. The vaccination campaign among people older than 65 living in Iporanga reached $72.4 \%$ of the target population, suggesting significant protection against $\mathrm{A} / \mathrm{Bayern} / 7 / 95$, which is antigenically and genetically related to A/Beijing/262/95, a component of the 1999 vaccine. Vaccines containing A/Beijing/262/95 (H1N1) stimulated postimmunization $\mathrm{HI}$ antibodies which were equivalent in frequency and titre to both A/Beijing/262/95-like and A/Bayern/7/95-like viruses $^{34}$. The effectiveness of influenza vaccine depends primarily on the age and immunocompetence of vaccine recipients and the degree of similarity between the virus strains in the vaccine and those in circulation, as demonstrated in this investigation by both virus isolation and characterization. When an antigenic match occurs between vaccine and the predominant circulating strains, approximately $70-90 \%$ of vaccinated healthy persons younger than 65 years are protected ${ }^{19}$. Among elderly persons living outside nursing homes or similar chronic-care facilities, influenza vaccine is $30-70 \%$ effective in preventing hospitalization for pneumonia and influenza ${ }^{16,17}$. For those persons residing in nursing homes, influenza vaccine is most effective in preventing severe illness, secondary complications, and deaths. Consequently, in this population the vaccine can be 50-60\% effective in preventing hospitalization or pneumonia and $80 \%$ effective in preventing death, even though the effectiveness in preventing influenza illness often ranges from $30 \%$ to $40 \%{ }^{21}$. This investigation also suggests vaccination strategies for the elderly who are at increased risk for complications from influenza.

This fact emphasizes the importance of maintenance of active surveillance of influenza circulation, so that a more adequate vaccine composition can be selected for each year.

\section{RESUMO}

\section{Epidemia de influenza A (H1N1) no Município de Iporanga, SP, Brasil}

Durante os meses de junho e julho de 1999, foram notificados 324 casos de doença respiratória aguda no Município de Iporanga-SP. O isolamento do vírus da influenza do tipo A/Bayern/07/95 (H1N1) e a conversão sorológica para a estirpe viral (H1N1) foram de $57,1 \%$ e $100 \%$, respectivamente. A porcentagem de casos com diagnóstico clínico notificados durante a epidemia foi de $28,4 \%, 29,0 \%, 20,7 \%, 6,2 \%$ e $15,7 \%$, nas faixas etárias de 0-4, 5-9, 10-14, 15-19 anos e indivíduos acima de 20 anos de idade, respectivamente. Observou-se maior incidência da doença entre os indivíduos menores de 14 anos. Atribui-se a ausência de notificação de casos em indivíduos maiores de 65 anos à campanha de vacinação, na população idosa de Iporanga, que em 1999 atingiu $72,4 \%$. O virus isolado é genética e antigenicamente semelhante à estirpe A/Beijing/262/95 (H1N1), o componente H1 da vacina de 1999. Vacinas contendo a estirpe A/Beijing/262/95 (H1N1) estimularam, após imunização, anticorpos inibidores da hemaglutinação, os quais foram equivalentes em frequiência e título para ambas as estirpes: A/Bayern/ 07/95 e A/Beijing/262/95.

\section{ACKNOWLEDGEMENT}

We would like to thank the personnel of the Iporanga Municipal Health Department.

Marcia Theobaldo and Ivani Bisordi Ferreira responsible for the serological tests to rubella-measles, and dengue, respectively.

Dr. João Toniolo-Neto, Dr. Eduardo Forléo-Neto and the Rn Elisa Halker from Federal University of São Paulo for contributing with Public Health improvement in Brazil regarding influenza virus vaccination campaigns in the elderly.

The personnel of the WHO Collaborating Center for Reference and Research on Influenza, CDC, Atlanta.

\section{REFERENCES}

1. BARKER, W.H. \& MULLOOLY, J.P. - Pneumonia and influenza deaths during epidemics: implications for prevention. Arch. intern. Med.,142: 85-89, 1982.

2. CATE, T.R. - Clinical manifestations and consequences of influenza. Amer. J. Med., 82 (suppl. 6A): 15-19, 1987.

3. CHIN, D.Y.; MOSLEY, W.M.; POLAND, J.D.; RUSH, D. \& JOHNSON, O. Epidemiologic studies of type B influenza in 1961-62. Amer. J. publ. Hlth., 53: 1068-1074, 1963.

4. DAVENPORT, F.M.; HENESSY, A.V. \& FRANCIS Jr., T. - Epidemiologic and immunologic significance of age distribution of antibody to antigenic variants of influenza virus. J. exp. Med., 98: 641-647, 1953.

5. FRANK, A.L.; TABER, L.H.; WELLS, C.R. et al. - Patterns of shedding of myxoviruses and paramyxoviruses in young children. J. infect. Dis., 144: 433-441,1981.

6. FRANK, A.L.; TABER, L.H. \& WELLS, J.M. - Individuals infected with two subtypes of influenza A virus in the same season. J. infect. Dis., 147: 120-124, 1983. 


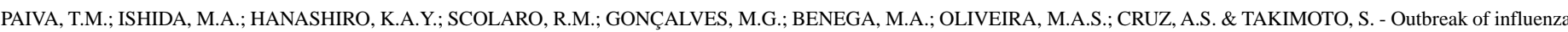
type A (H1N1) in Iporanga, São Paulo State, Brazil. Rev. Inst. Med. trop. S. Paulo, 43(6):311-315, 2001.

7. GLESEN, W.P. - Serious morbidity and mortality associated with influenza epidemics. Review. Epidem. Rev., 4: 25-44, 1982.

8. HALL, C.E.; COONEY, M.K. \& FOX, J.P. - The Seattle virus watch. IV. Comparative epidemiologic observations of infections with influenza A and B viruses, 1965-69, in families with young children. Amer. J. Epidem., 98: 365-380, 1973.

9. IZURIETA, H.S.; THOMPSON, W.W.; KRAMARZ, P. et al. - Influenza and the rates of hospitalization for respiratory disease among infants and young children. New Engl. J. Med., 342: 232-239, 2000.

10. KENDAL, A.P.; LEE, D.T.; PARISH, H.S. et al. - Laboratory-based surveillance of influenza virus in the United States during the winter of 1977-1978. II. Isolation of a mixture of A/Victoria and A/USSR-like viruses from a single person during an epidemic in Wyoming, USA, January 1978. Amer. J. Epidem., 110: 462-468, 1979.

11. KÖPPEN, W.P. - Clima. In: Enciclopédia Mirador Internacional. São Paulo, Enciclopédia Britânica do Brasil, 1995. v.6, p. 2559-2560.

12. KUNG, H.C.; JEN, K.F.; YUAN, W.C.; TIEN, S.F. \& CHU, C.M. - Influenza in China in 1977: recurrence of influenza virus A subtype H1N1. Bull. Wld. Hlth. Org., 56: 913-918, 1978.

13. KUNO, G.; GÓMEZ, I. \& GUBLER, D.J. - Detecting artificial anti-dengue IgM immune complexes using an enzyme-linked immunosorbent assay. Amer. J. trop. Med. Hyg., 36: $153-159,1987$.

14. LUI, K.J. \& KENDAL, A.P. - Impact of influenza epidemics on mortality in the United States from October 1972 to May 1985. Amer. J. publ. Hlth., 77: 712-716, 1987.

15. MONTO, A.S. \& KIOUMERH, F. - The Tecumsed study of respiratory illness. IX Occurrence of influenza in the community 1966-71. Amer. J. Epidem., 102: 553$563,1975$.

16. MULLORY, J.P.; BENNETT, M.D.; HORNBROOK, M.C. et al. - Influenza vaccination programs for elderly persons: cost-effectiveness in a health maintenance organization. Ann. intern. Med., 121: 947-952, 1994.

17. NICHOL, K.L.; MARGOLIS, K.L.; WUORENMA, J. \& Von STERNBERG, T. - The efficacy and cost effectiveness of vaccination against influenza among elderly persons living in the community. New Engl. J. Med., 331: 778-784, 1994.

18. PAIVA T.M.; ISHIDA, M.A.; FORLÉO-NETO, E. et al. - Epidemiological study of influenza virus in Brazil from 1996-98. Virus Rev. Res., 5: 51-63, 2000.

19. PALACHE, A.M. - Influenza vaccines: a reappraisal of their use. Drugs, 54: 841-846, 1997.

20. PALMER, D.F.; COLEMAN, M.T.; DOWDLE, W.R. \& SCHILD, G.C. Hemagglutination-inibition test. In: WELFARE, P.H.S., ed. Advanced laboratory techniques for influenza diagnosis. Atlanta, U.S. Dept. Hlth.,1975. p. 25-62.

21. PATRIARCA, P.A.; WEBER, J.A.; PARKER, R.A. et al. - Efficacy of influenza vaccine in nursing homes: reduction in illness and complications during an influenza $\mathrm{A}(\mathrm{H} 3 \mathrm{~N} 2)$ epidemic. J. Amer. med. Ass., 253: 1136-1139, 1985.

22. PERROTTA, D.M.; DECKER, M. \& GLEZEN, W.P. - Acute respiratory disease hospitalizations as a measure of impact of epidemic influenza. Amer. J. Epidem. 122: 468-476, 1985.
23. PHILIP, R.N.; BELL, J.A.; DAVIS, D.J. et al. - Epidemiologic studies on influenza in familial and general population groups, 1951-56. II. Characteristics of occurrence. Amer. J. Hyg., 73: 123-137, 1961.

24. SMITH, A.J. \& DAVIES, J.R. - Natural infection with influenza A (H3N2). The development, persistence and effect of antibodies to the surface antigens. J. Hyg. (Lond.), 77: 271-282, 1976.

25. SPRENGER, M.J.W.; VAN NAELTEN, M.A.M.G.; MULDER, P.G.H. \& MEASUREL, N. - Influenza mortality and excess deaths in the elderly, 1967-1982. Epidem. Infect., 103: 633-641, 1989

26. STUART-HARRIS, C. - Epidemiology of influenza in man. Brit. med. Bull., 35: 3-8, 1979.

27. SZUCS, T.D. - Influenza. The role of burden-of-illness research. Pharmacoeconomics, 16 (suppl. 1): 27-32, 1999.

28. TABER, L.H.; PAREDES, A.; GLESEN, W.P. \& COUCH, R.B. - Infection with influenza A/Victoria virus in Houston families, 1976. J. Hyg. (Lond.), 86: 303-313, 1981

29. TAKIMOTO, S.; GRANDIEN, M.; ISHIDA, M.A. et al. - Comparison of enzyme-linked immunosorbent assay, indirect immunofluorescence assay, and virus isolation for detection of respiratory viruses in nasopharyngeal secretions. J. clin. Microbiol. 29: 470-474, 1991.

30. TONIOLO-NETO, J.; WECKX, L.W.; HALKER, E. et al. - Safety of simultaneous pneumococcal and influenza vaccination in elderly patients in Brazil. Drugs Aging, 15(suppl. 1): S43-S45, 1999.

31. WEINBERG, A.; FINK, M.C.D.S.; TAKIMOTO, S.; ISHIDA, M.A. \& SOUZA, M.C Enzyme linked immunosorbent assay: determination of anti-adenovirus antibodies in an infant population. Rev. Inst. Med. trop. S. Paulo, 31: 336-340, 1989

32. WORLD HEALTH ORGANIZATION - WHO influenza surveillance. Wkly. epidem. Rec., 71: 353-360, 1996.

33. WORLD HEALTH ORGANIZATION - Recommended composition of influenza virus vaccines for use in the 1997-1998 season. Wkly. epidem. Rec., 72: 57-60, 1997.

34. WORLD HEALTH ORGANIZATION - Recommendation for the composition of influenza virus vaccines for use in 1999. Wkly. epidem. Rec., 73: 305-308, 1998.

35. WORLD HEALTH ORGANIZATION - Influenza vaccines. Wkly. epidem. Rec., 75: $281-288,2000$

36. WRIGHT, P.F.; THOMPSON, J. \& KARZON, D.T. - Differing virulence of H1N1 and H3N2 influenza strains. Amer. J. Epidem., 112: 814-819, 1980.

37. YAMANE, N.; ARIKAWA, J.; ODAGIRI, T.; SUKENO, N. \& ISHIDA, N. - Isolation of three different influenza $A$ viruses from an individual after probable double infection with H3N2 and H1N1 viruses. Jap. J. med. Sci. Biol., 31: 431-434, 1978.

Received: 24 May 2000

Accepted: 2 October 2001 